\title{
連載講座
}

||||||||||||||||||||||||||||||||||||||||

\section{TRT・TAT の更なる活性化に向けて}

\section{TRT ・ TAT への期待 - 基礎研究・開発研究の観点から-}

\author{
李 惠子, 長谷川純崇 ${ }^{\dagger}$ \\ 国立研究開発法人量子科学技術研究開発機構放射線医学総合研究所 \\ ${ }^{\dagger}$ hasegawa.sumitaka@qst.go.jp
}

\begin{abstract}
標的アイソトープ治療（TRT）は細胞殺傷性の粒子放射線を放出するラジオアイソトープ (RI) を 用いた治療で, 癌治療の選択肢の一つとして確立している。ヨウ素 131 が甲状腺疾患の治療に用 いられて以来，TRT は長い歴史を持つ治療法である。ヨウ素131やイットリウム 90 のような $\beta$ 線 放出核種が主にTRTで使われてきた。放射化学や加速器工学の最近の進歩により, 標的 $\alpha$ 線治療 (TAT) が癌治療の選択肢として注目を集めている。 $\alpha$ 線は $\beta$ 線と比較して高い細胞殺傷能を有する。 また， $\alpha$ 線は短い飛程である。この性質により，標的細胞に $\alpha$ 線が送達された場合，周囲組織を正 常に保ちながら標的細胞だけを殺傷することが出来る。TAT の開発研究は盛んになりつつある。
\end{abstract}

Key Words: radioisotopes, targeted radionuclide therapy (TRT), targeted alpha therapy (TAT), radiopharmacology, radiation oncology

\section{1. はじめに}

標的アイソトープ治療 (targeted radionuclide therapy, TRT) はラジオアイソトープ (radioisotope, RI）標識化合物を体内に投与し, 病巣へ特 異的に集積した RI からの放射線が病巣を直接 照射する治療法である。TRT の中でも, 特に, がん細胞等の標的細胞や組織に対して $\alpha$ 線を特 異的に送達して治療する方法については, 標的 $\alpha$ 線治療（targeted alpha therapy, TAT）と言われ ている。

\section{TRT と TAT の現状}

TRT は, 1940 年代に行われたヨウ素 131 $\left({ }^{131} \mathrm{I}\right)$ を用いた分化型甲状腺癌の治療から始ま り, ストロンチウム $89{ }^{89} \mathrm{Sr}$, 商品名メタスト ロン）による骨転移腫瘍の疼痛緩和療法など, 生体の特異的な取込機序が利用された。1990 年代には, RI 標識モノクローナル抗体を用い た放射免疫療法 (radioimmunotherapy, RIT) が
登場した。B 細胞性非ホジキンリンパ腫の治 療薬として, 抗 CD20 モノクローナル抗体に イットリウム $90\left({ }^{90} \mathrm{Y}\right.$, 商品名ゼヴァリン) とヨ ウ素 $131\left({ }^{131} \mathrm{I}\right.$, 商品名ベキサール) をそれぞれ 標識した放射性医薬品が立て続けに米国で承 認され，標準治療に組み込まれ，この分野が一 気に活気づいた。2010 年頃から神経内分泌腫 瘍に対する RI 標識ソマトスタチンアナログを 用いたペプチド受容体放射性アイソトープ療 法 (peptide receptor radionuclide therapy, PPRT) が海外で盛んに行われ，2017年にルテチウム 177 標識ソマトスタチンアナログ $\left({ }^{177}\right.$ Lu-DOTATATE, 商品名ルタセラ) が神経内分泌腫瘍に対 する治療薬として欧州で承認された。このよ うに, 標的アイソトープ治療では, 古くから $\beta$ 線放出核種のみがルーチンで臨床利用されて いたが，近年 $\alpha$ 線放出核種の医学利用に注目が 集まっている。2013 年に去勢抵抗性前立腺癌 骨転移に対する塩化ラジゥム $223\left({ }^{223} \mathrm{Ra}\right.$, 商品 名ゾーフィゴ) が最初の $\alpha$ 線放射性薬剤として 
FDA で承認され，市場規模が大きくない放射 性薬剤としては, 初のブロックバスター薬剤と なった。その翌年にはアクチニウム 225 標識前 立腺特異的膜抗原 ${ }^{225}$ Ac-PSMA) が $\beta$ 線では制 御できなかった前立腺多発転移を完全宽解させ たという症例報告があり ${ }^{1)}$, TRT における $\alpha$ 線 の有効性が臨床でも証明され, TAT の開発研究 が加速した。また，オージェ電子放出核種を用 いた TRTの基礎研究や薬郕開発も行われてお り, その臨床応用が期待されている。TRTの対 象としてがんがまず挙げられるが, その他にも 甲状腺機能充進症の治療, 造血幹細胞移植の前 処置, さらには感染症治療等の分野で臨床利用 や開発研究も進められており, 今後より多くの 患者がTRT の恩恵を受けるようになることが 期待されている。

\section{3. がん治療における克服すべき課題と TRT の利点}

がんの標準療法として, 従来の3 本柱であ 万外科療法, 放射線療法, 薬物療法 (化学療法 と分子標的治療) に免疫療法が加わり, もはや

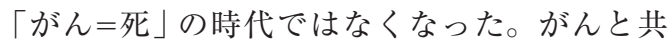
存して長生きすることができるようになった 今, がん治療において, がんを治して命を救う だけではなく，患者の生活の質 (quality of life, QOL) 向上も求められ, 低侵襲で早期社会復帰 が可能な治療法が求められる。血液悪性腫瘍な ど特殊ながんを除けば，一般的にがんは局所の 原発巣から始まり, 進行すると周辺の正常組織 へ浸潤，また，血流を介して遠隔転移を形成す る。治療後に残存した微小がんが再び大きくな り再発することもある。早期診断や治療技術の 進歩により，がんが原発巣に限局するときの治 癒率は向上したが，遠隔転移が形成された進行 例や再発例の予後は依然として極めて不良であ る。転移や再発の原因となる微小がんはいずれ も体内に散在するため, 視覚的に標的を捉える 外科療法や外部照射による放射線療法では制御 が難しい。そこで, 薬物療法, 免疫療法が用い
られるのだが，副作用や薬剤耐性の獲得などが 懸念される。

TRT は，体内で RI ががん患部に特異的に集 積し，RIから放出される放射線が病巣を直接 照射するため, 視覚的に治療部位を設定する必 要はなく, 体内に散在する血液悪性腫瘍, 転 移,さらには検出できない微小がんにも適応で きる。照射する際に正常組織を経由しないの で，外部照射による放射線療法に比べて正常組 織の被ばくを軽減できる。治療用 RI の代わり に, イメージング用 RIを同一化合物に標識し たものを用いることで, 治療 (therapeutics) と 診断 (diagnostics) を同時にできる，いわゆるセ ラノスティックス (theranostics) が可能である。 治療前に腫瘍の分布, 放射性薬棛の体内動態や 各臓器における被ばく線量を検証し, 重要臓器 への非特異的集積の有無など副作用を事前に確 認・回避することができる。薬剤が排出され ず，体内に残存した際も RI が自動的に減衰し 消失するため, 抗がん剂などに比べて毒性は低 いと考えられる。標的となる受容体等ががん細 胞に発現している限り，RIががん細胞に輸送 され，放射線によって細胞を殺傷するため，既 に薬剤耐性を獲得したがんにも適応できる。ま た，放射性薬剂を投与する治療法なので，使用 する治療用 RIによっては，放射能が減衰する までに短期の入院が必要となることもあるが, 低侵襲で早期に社会復帰できる治療法であると 考えられる。適材適所の言葉通り，それぞれの 治療法に異なる利点があって，標的となるがん の病態によって最も有効となる治療法を選択す べきであるが，TRTは，現在臨床で頻繁に利用 される標準治療を用いてもなお残る克服すべき 課題に対応できる治療法であると考えられる。

\section{TRT の理想型}

いかなる治療においても, 最小限の副作用で 高い治療効果をもつことが重要であり, TRTも 論外ではない。放射性薬剤を用いる TRTにお いて，如何にそれを可能にするのかを治療効果 


\begin{tabular}{ccc}
\hline$\alpha$ 線 & $\beta$ 線 & オージェ電子 \\
\hline LET:50-100 keV $/ \mu \mathrm{m}$ & LET:0.3 keV $/ \mu \mathrm{m}$ & LET:4-26 keV $/ \mu \mathrm{m}$
\end{tabular}

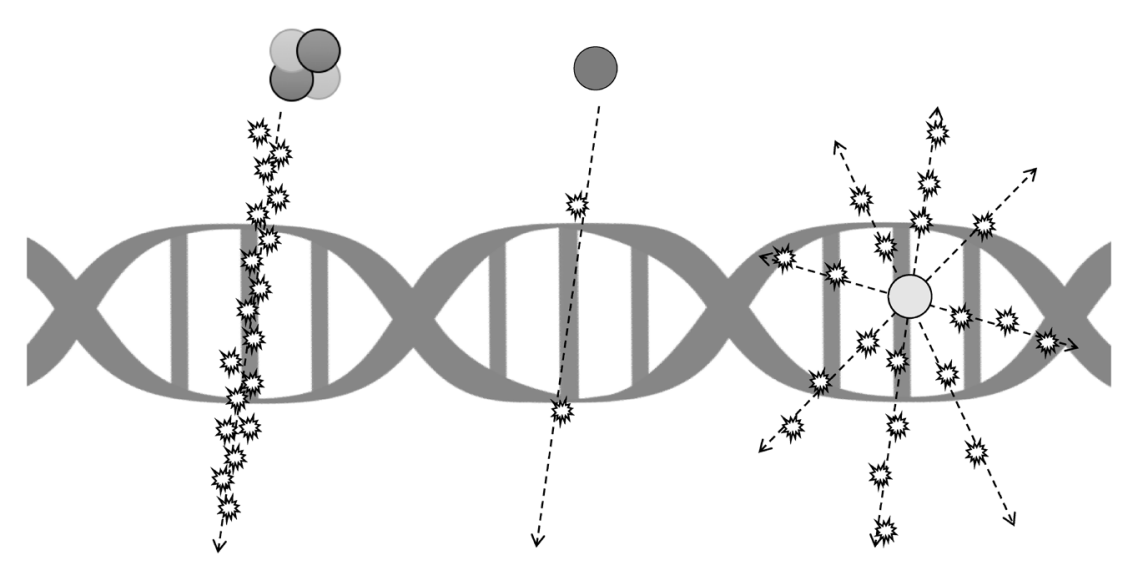

図 1 TRT で用いられる粒子放射線

と副作用に分けて考える。

TRT では, RI をがん特異的に集積させるこ とが大前提で最も重要であり, 治療効果向上と 副作用低減の双方に寄与する。がん患部にただ 集積させるだけではなく，標的となる全てのが ん細胞が照射によって直接ないしは間接的に殺 傷される必要があるため, 細胞殺傷能の高い RI の利用やがん組織内での RI 分布の均一化な どの工夫が求められる。 RI ががん組織に集積・ 照射した後は, 必要以上に体内に留まる必要が なく，正常組織への不要な被ばくを避けるため にも, 迅速にがん患部に集積し, 迅速に排泄さ れる放射性薬剂の開発が期待される。放射性薬 剤を用いた治療であり, 体内で標識された RI が外れることが考えられるため, 正常組織への RI の生理的集積に対する回避策や体内で安定 な標識法の開発が必要となる。このように, 理 想的な TRT を実現化するためには, 利用する RI (放射線, 飛程, 半減期), 標識化合物, 標 識法, 併用薬剤など, 標的となるがんの病態に 合わせて, これらを適材適所で選択し組み合わ せることが重要となる。

\section{TRT に用いられる放射線}

放射線と一言でいっても, 一般的に知られ
ているX線をはじめ種類はさまざまで，その 生物学的効果は線質によって異なる。TRTで 用いられる治療用 RI としては, 壊変時に $\beta$ 線, $\alpha$ 線，オージェ電子などを放出するものが用い られる(図1)。それぞれ物理学的性質 (飛程と 線エネルギー付与 (linier energy transfer, LET) が異なるため, 治療標的の病態によって選択さ れる。

$\beta$ 線は原子核が $\beta$ 崩壊する際に高速で放出さ れる質量の小さな電子で, 古くから TRT に用 いられてきた。その組織内飛程は長く(0.05$12 \mathrm{~mm}), \mathrm{RI}$ が集積していない近傍の細胞に対し ても cross-fire effectにより同様に照射できると いう利点を持つが, 同時に周辺の正常組織への 被ばくが懸念される。 $\beta$ 線の LET は約 $0.2 \mathrm{keV} /$ $\mu \mathrm{m}$ で, 距離に依存せず常に一定である。一般 的に, 細胞分裂の頻度が高い組織ほど放射線感 受性が高いとされており， $\beta$ 線は分裂が盛んな 血液のがんには効果的である。

$\alpha$ 線は $\alpha$ 崩壊に伴って放出されるへリウム原 子核で, 質量は重く速度が遅いので, 電離が 密におこり，止まる直前がとくに著しい。そ の LET は約 $80 \mathrm{keV} / \mu \mathrm{m}$ と最も高く, ブラック ピーク近辺では約 $240 \mathrm{keV} / \mu \mathrm{m}$ にも達する。高 細胞殺傷能をもつ高 LET 放射線として, 放射 
線抵抗性とされる固形がんに対しても効果的 であると， $\alpha$ 線の医学利用に注目が集まってお り, 活発な開発研究が行われている。 $\alpha$ 線は透 過力が小さく, 紙で遮蔽でき, 組織内飛程は 40-100 $\mu \mathrm{m}$ と細胞数個分である。がん特異的に 集積することで, 非標的である周辺正常組織へ のダメージを軽減できる利点をもつ。飛程の短 さゆえ, 転移や微小がんがよい適応となる。サ イズの大きながんを標的とする場合には，腫瘍 内での RI 集積分布を均一にするなどの工夫が 必要となる。

オージェ電子は励起状態にある原子が基底 状態に遷移するときに放出される電子であ る。オージェ電子の LET は 4- $26 \mathrm{keV} / \mu \mathrm{m}$ であ る。組織内飛程は2-500 nm であるため, その 細胞殺傷能を最大限に活かすためには，RIを 細胞に集積させるだけでなく，主な標的であ る DNA 近傍まで輸送する必要があるが，標的 以外の組織への被ばくは極めて低いと考えら れる。実際に核移行シグナルを用いることで, オージェ電子放出各種を細胞核内輸送し, 殺細 胞効果を高めることができるという研究成果が 報告されている。現在 $\alpha$ 線による TRT の第 2 波 がきているとすれば，オージェ電子は第 3 波と して期待される。TRTに利用される放射線は, 標的となる患部のサイズや放射線感受性などに よって選択される。

\section{6. 治療用 RI}

TRT に用いる RI 選択する際の判断要素と して, 前項で説明した放出する放射線の種類, 半減期, そして生体内での生理的集積などが挙 げられる。

$\beta$ 線放出核種としては, ${ }^{131} \mathrm{I}$ (半減期 $\left.\mathrm{h}_{1 / 2}=8.02 \mathrm{~d}\right),{ }^{89} \mathrm{Sr}(50.57 \mathrm{~d}),{ }^{90} \mathrm{Y}(2.67 \mathrm{~d}),{ }^{177} \mathrm{Lu}$ $(6.73 \mathrm{~d})$ が主に臨床利用されている。 $\alpha$ 線放出 核種として, ${ }^{223} \mathrm{Ra}(11.4 \mathrm{~d}),{ }^{211} \mathrm{At}(7.2 \mathrm{~h}),{ }^{225} \mathrm{Ac}$ $(10 \mathrm{~d}),{ }^{213} \mathrm{Bi}(45.6 \mathrm{~min}),{ }^{212} \mathrm{~Pb}(10.6 \mathrm{~h})$ が主に挙 げられ，うち ${ }^{223} \mathrm{Ra}$ のみが臨床利用されている。 オージェ電子放出核種として, ${ }^{111} \operatorname{In}(2.8 \mathrm{~d})$,
${ }^{64} \mathrm{Cu}$ (12.7)， ${ }^{77} \mathrm{Br}(57.0$ h) が臨床応用に向けた開 発研究が行われている。生体内で ${ }^{131} \mathrm{I}$ は甲状腺 に, ${ }^{89} \mathrm{Sr}$ と ${ }^{223} \mathrm{Ra}$ は骨に特異的に取り达まれる ため, 標識化合物を必要とせずに甲状腺癌の治 療や骨転移の治療に利用できる。 ${ }^{211} \mathrm{At}{ }^{131} \mathrm{I}$ と 同じハロゲンであり，甲状腺に特異的に取り込 まれるが，安定同位体が存在しないため，その 化学的性質が十分に知られていないことから, 化合物への標識体での臨床利用を中心に研究開 発されている。 ${ }^{211} \mathrm{At}$ の半減期は治療用 RI とし て, 比較的短いが, 強力な $\alpha$ 線を放出する故, 病巣照射後に迅速に減衰することが望ましいこ と，サイクロトロンを用いて製造できること，

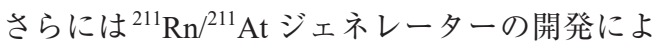
り治療用 RI としての開発研究が活発に行われ ている。 ${ }^{225} \mathrm{Ac}$ は壊変する際に 4 回 $\alpha$ 線を放出 することで，非常に高い注目を集める $\alpha$ 線放出 核種の一つである。 ${ }^{213} \mathrm{Bi}$ は ${ }^{225} \mathrm{Ac}$ の娘核種であ る。オージェ電子を放出する ${ }^{111} \mathrm{In}$ は $\gamma$ 線, ${ }^{64} \mathrm{Cu}$ は $\beta^{+}$線をも放出するためそれぞれ SPECT, PET 核種としてイメージング用 RI としても用いら れ，セラノスティックスを可能とする。

\section{TRT や TAT の基礎研究や薬剤開発}

近年, TAT の治療有効性が明らかになりつつ あり, 次世代の革新的な TAT 開発に向けた基 礎研究や研究開発も活発化している。

$\alpha$ 線放出の ${ }^{211} \mathrm{At}$ を様々な抗体に搭載すること で，がん細胞に特異的に送達する試みがなさ れている。例えば，抗 HER 抗体であるトラス ツズマブを用いた HER2 陽性胃癌腹膜播種に 対する実験治療 ${ }^{2)}$, 滑膜肉腫で高発現している FZD10 標的とした研究開発 ${ }^{3)}$ ，また，免疫関 連因子である MICA/B を標的とした TAT 非臨 床研究 ${ }^{4)}$ やクリアランスが早い低分子量の抗体

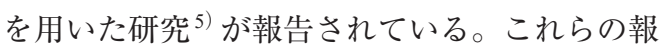
告では， $\alpha$ 線による治療の有効性が示されてい るだけではなく, ${ }^{211} \mathrm{At}$ 投与における重篤な毒 性がないことも示されており, 臨床への展開が 期待されている。送達の手段として，抗体だけ 
ではなく，低分子化合物の利用も報告されてい る。例えば, meta- ${ }^{211}$ At-astato-benzylguanidine ${ }^{6)}$ やシグマ受容体 ${ }^{7)}$ に結合リガンドに ${ }^{211} \mathrm{At}$ を標 識した化合物が報告されている。更に, ${ }^{211} \mathrm{At}$ 単体での TATの可能性も動物実験で示されて

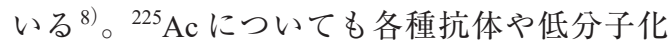
合物を送達体とした標識化合物が合成され，そ の治療有効性や毒性について非臨床開発が行わ れている。

$\beta$ 線利用についてはすでに臨床で応用されて

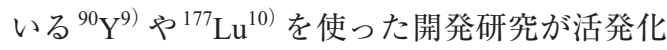
している。PETによる画像化も可能な ${ }^{64} \mathrm{Cu}$ を 使った研究 ${ }^{11)} も$ 行われている。

オージェ電子に関しては, DNA が細胞傷害 の主たる標的と考えると，オージェ電子の飛 程 (nm オーダー) を考えて DNA の近傍にオー ジェ電子放出 RI を送達させる戦略で開発研究 が進んでいる ${ }^{12)}$ 。例えば, トラスッズマブに 核移行シグナルをつけてオージェ電子放出 ${ }^{111} \mathrm{In}$ を送達して細胞障害を誘導する試みがなされて いる ${ }^{13)}$ 。オージェ電子利用の興味深い試みと して, オージェ電子放出の白金 $\left({ }^{195 \mathrm{~m}} \mathrm{Pt}\right.$ や $\left.{ }^{191} \mathrm{Pt}\right)$ を使ったオージェ電子シスプラチン治療が挙げ られる。シスプラチンは DNA と結合して効果 を発揮する抗がん剤として長く使われてきた。 実験動物を用いた非臨床試験では治療効果も確 認されており，今後の展開が期待される。

\section{8. おわりに}

今後の TRT・TAT の発展を考える上で, 基 礎研究分野においては新規放射性薬剤の開発が 重要であることは論を俟たない。昨今の免疫 チェックポイント阻害剤をはじめとする免疫治 療の発展から明らかであるが, 革新的な医学の イノベーションは, 長年の地道な基礎研究の成 果を基に生まれる。

開発においては， $\alpha$ 線標的アイソトープ治療 が真に効果的な疾患やがん種, 病態を十分に検 討することが重要であろう。 $\alpha$ 線の飛程やその 高い生物効果を考えると, 従来の $\beta$ 線では治療
が困難であった固形がんの微小転移・播種が今 のところ最も好適な標的と考えている。また, $\alpha$ 線は病変局所に重篤で多彩な病理学的変化を 引き起こすと考えられるので，局所での免疫 微小環境の変化や殺傷された細胞の免疫原性, DNA 損傷修復を起因とした免疫反応性や細胞 死モードの研究は今後, 生物にバックグランド を持つ研究者らが中心となって研究すべき課題 であると思われる。

TRT ・ TAT の開発研究や生物研究は更なる発 展が期待できる分野であると確信する。

\section{文献}

1) Kratochwil, C., Bruchertseifer, F., Giesel, F. L., Weis, M., et al., 225Ac-PSMA-617 for PSMATargeted alpha-Radiation Therapy of Metastatic Castration-Resistant Prostate Cancer, J. Nucl. Med., 57, 1941-1944 (2016)

2) Li, H. K., Morokoshi, Y., Nagatsu, K., Kamada, $\mathrm{T}$., et al., Locoregional therapy with alpha-emitting trastuzumab against peritoneal metastasis of human epidermal growth factor receptor 2-positive gastric cancer in mice, Cancer Sci., 108, 1648-1656 (2017)

3) Li, H. K., Sugyo, A., Tsuji, A. B., Morokoshi, Y., et al., alpha-particle therapy for synovial sarcoma in the mouse using an astatine-211-labeled antibody against frizzled homolog 10, Cancer Sci., 109, 2302-2309 (2018)

4) Li, H. K., Hasegawa, S., Nakajima, N. I., Morokoshi, $\mathrm{Y}$., et al., Targeted cancer cell ablation in mice by an alpha-particle-emitting astatine-211-labeled antibody against major histocompatibility complex class I chain-related protein A and B, Biochem. Biophys. Res. Commun., 506, 1078-1084 (2018)

5) Choi, J., Vaidyanathan, G., Koumarianou, E., Kang, C. M., et al., Astatine-211 labeled anti-HER2 5F7 single domain antibody fragment conjugates: radiolabeling and preliminary evaluation, Nucl. Med. Biol., 56, 1-20 (2018)

6) Ohshima, Y., Sudo, H., Watanabe, S., Nagatsu, K., et al., Antitumor effects of radionuclide treatment using alpha-emitting meta-(211)At-astato-benzylguanidine in a PC12 pheochromocytoma model, Eur. J. Nucl. Med. Mol. Imaging, 45, 999-1010 (2018)

7) Ogawa, K., Mizuno, Y., Washiyama, K., Shiba, $\mathrm{K}$., et al., Preparation and evaluation of an astatine- 
211-labeled sigma receptor ligand for alpha radionuclide therapy, Nucl. Med. Biol., 42, 875-879 (2015)

8) Watabe, T., Kaneda-Nakashima, K., Liu, Y., Shirakami, Y., et al., Enhancement of (211)At Uptake via the Sodium Iodide Symporter by the Addition of Ascorbic Acid in Targeted alpha-Therapy of Thyroid Cancer, J. Nucl. Med., 60, 1301-1307 (2019)

9) Sudo, H., Tsuji, A. B., Sugyo, A., Saga, T., et al., Therapeutic efficacy evaluation of radioimmunotherapy with (90) Y-labeled anti-podoplanin antibody NZ-12 for mesothelioma, Cancer Sci., 110, 1653-1664 (2019)

10) Phaeton, R., Jiang, Z., Revskaya, E., Fisher, D. R., et al., Dadachova E. Beta emitters rhenium-188 and lutetium-177 are equally effective in radioimmunotherapy of HPV-positive experimental cervical cancer, Cancer Med., 5, 9-16 (2016)

11) Jin, Z. H., Tsuji, A. B., Degardin, M., Sugyo, A., et al., Uniform intratumoral distribution of radioactivity produced using two different radioagents, (64) Cucyclam-RAFT-c(-RGDfK-)4 and (64)Cu-ATSM, improves therapeutic efficacy in a small animal tumor model, EJNMMI Res., 8, 54 (2018)

12) Ku, A., Facca, V. J., Cai, Z. and Reilly, R. M., Auger electrons for cancer therapy-a review, EJNMMI Radiopharm Chem, 4, 27 (2019)

13) Li, H. K., Morokoshi, Y., Daino, K., Furukawa, T., et al., Transcriptomic Signatures of auger electron radioimmunotherapy using nuclear targeting (111) in-trastuzumab for potential combination therapies, Cancer Biother. Radiopharm., 30, 349-358 (2015)

\section{Abstract}

It's Time to Pump Up the TRT/TAT in Japan A Perspective in TRT and TAT - Basic and Translational Sciences-

Huizi Keiko Li and Sumitaka HaSEGAWA ${ }^{\dagger}$ : National Institute of Radiological Sciences, National Institutes for Quantum and Radiological Science and Techonology, ${ }^{\dagger}$ hasegawa.sumitaka@qst.go.jp

Targeted radionuclide therapy (TRT) uses radioisotopes (RIs) that emit cytotoxic particle radiation and has been established as a therapeutic option for cancer. TRT has a long history since ${ }^{131} I$ was used for the treatment of thyroid diseases. $\beta$-particle emitters such as ${ }^{131} I$ and ${ }^{90} Y$ have been utilized mainly in TRT. Recently progress on radiochemistry and accelerator engineering make targeted alpha therapy (TAT) an attractive therapeutic option of cancer therapy because $\alpha$-particle beam has higher cytotoxicity than $\beta$-particle. $\alpha$-particle beam has very short path length; when precisely delivered to target, only target cells should be killed sparing the surrounding non-target cells. Research and development for TAT is now under active investigation. 